\title{
Effect of Mono Ethylene Glycol solution on mechanical behavior of a
}

\author{
clay soil
}

\author{
A. R. Estabragh \\ Associate Professor. Faculty of Soil and Water Engineering, University of Tehran, \\ PO BOX 4411 Karaj 31587-77871, Iran \\ Corresponding Author: A.R. Estabragh \\ ORCID: 0000-0003-4545-2310 \\ Tel: +98 2632241119 \\ Fax: +98 2632226181 \\ Email: raeesi@ut.ac.ir

\section{Beytolahpour} \\ Postgraduate Student, Faculty of Soil and Water Engineering, University of Tehran, \\ PO BOX 4411 Karaj 31587-77871, Iran \\ Tel: +982632241119 \\ Fax: +98 2632226181 \\ Email: beitolahpour@ut.ac.ir
}

\section{A. A. Javadi}

Professor. Computational Geomechanics Group, Department of Engineering, University of Exeter, Devon, EX4 4QF, UK

Tel: +44 1392723640

Fax: +44 1392217965

Email: A.A.Javadi@exeter.ac.uk 


\title{
Effect of Mono Ethylene Glycol solution on mechanical behavior of a clay soil
}

\begin{abstract}
This paper presents the results of an investigation into the behaviour of a clay soil contaminated with Mono Ethylene Glycol (MEG) through a program of experimental tests. Soil samples were prepared with water or different concentrations $(10,25$ and $40 \%$ ) of MEG by the slurry method. One dimensional consolidation and consolidated undrained (CU) triaxial tests were performed on the samples. The results of the consolidation tests showed that the preconsolidation pressure is increased and value of $\lambda$ (slope of normal consolidation line) is decreased with increasing the concentration of MEG. In addition, the results of the CU triaxial tests indicated that the friction angles (in term of total and effective stresses) are greater for MEG solution than water as pore fluid and their values are increased with increasing the concentration of MEG solution. It was also shown that Roscoe surface exists for contaminated soil in $q, p^{\prime}$, $v$ space and its position in this space is dependent on the concentration of pore fluid. Keywords: contaminated soil, Mono Ethylene Glycol, consolidation test, consolidated undrained test, friction angle, Roscoe surface
\end{abstract}




\section{1- Introduction}

Pollution of the environment by petroleum hydrocarbons originates from many sources such as oil well drilling and production operations, transportation and storage in the upstream industry and refinery, transportation and marketing in the downstream industry. Spilled petroleum hydrocarbons in the environment usually flow into the soil due to gravity until an impervious horizontal layer is met. Interaction between soil and hydrocarbon is dependent on many factors such as particles size and type of soil minerals.

Soil are divided into granular (noncohesive) and cohesive groups. Granular soils are composed of inert particles but cohesive soils are composed of charged particles. The magnitude of charge for particles in cohesive soils is dependent on the type of its minerals. This difference between granular and cohesive soils causes a different interaction of them with hydrocarbon contaminants. Fang [1] proposed an index, so called sensitivity index, to describe the interaction of hydrocarbons with particles of soil. The value of this index was defined between 0 and 1 so that, for granular soil it is in the range of $0.01-0.1$ and for cohesive soil it varies in the range of 0.6 to 0.9 . The interaction between soil particles and hydrocarbons is in the form of mechanical or physicochemical interaction. In granular soils the mechanical interaction occurs that causes the soil particles to rotate and translate at contacts. In cohesive soil the physicochemical interaction is more prevalent than the mechanical interaction. The hydrocarbon influences the diffuse double layer of cohesive soils and makes some changes to the structure of the cohesive soil mass.

Meegoda and Rajapakse [2] and Ratnaweera and Meegoda [3] proposed the concept of short-term and long-term conditions for contaminated soil. A soil mass consists of solid particles with pores between them. The pores may be full of air, partial fluid and 
air or fluid. In short term, the air or a part of existing fluid in the pores may be replaced under a specific condition by a chemical fluid. This chemical fluid may cause a change in physical and mechanical behavior of soil. In long term, all the pores between the particles are filled by a chemical fluid due to replacement and this condition is the worst-case scenario because all the particles contribute to the interaction with chemical fluid and maximum interaction occurs in the soil mass. Some researchers (e.g., [4]-[13]) have studied some aspects of the behavior of cohesive soils (such as compressibility, hydraulic conductivity and consolidation) due to contamination with organic fluids. Review of the work carried out by these researchers (e.g., [4]-[13]) indicates that although significant amount of work has been done on the compressibility, hydraulic conductivity and consolidation behavior of cohesive soils due to contamination with different organic fluids, investigation on their undained shear strength behavior due to different contaminating fluids is very limited. To the authors' knowledge, up to now, the majority of the research that have been conducted for investigation of the shear strength of soil contaminated with organic fluid were in the short term condition For example, Sridharan and Rao ([14][15]) found from their experimental tests on contaminated clay that increase in shear strength is due to the decrease in dielectric constant of the pore fluid. Some researchers (e.g., [16]-[19]) studied the mechanical behaviour of sand contaminated with oil. They reported a reduction in friction angle for soil contaminated with oil. Ratnaweera and Meegoda ([3]) conducted unconfined compression and consolidated drained triaxial tests on fine grained and granular soils that were contaminated with different contaminating matters. Their results showed that the strength and friction angle are decreased with increasing the concentration of the contaminating matter. Rajabi et al. [20] examined the effect of crude oil on the shear modulus of a sandy soil 
and found that the change in the value of shear strength is dependent on the percent of used crude oil. Reviewing the works of above researchers indicates that the soils used in the previous research works were mainly granular; therefore, the reduction in friction angle and amount of it can be attributed to the type and amount of contaminating matter. Singh et al. [11] conducted different tests on natural (CL and $\mathrm{CH}$ ) soils and soils that were contaminated with 3,6 and 9\% used motor oil. They found that the friction angle decreased but the apparent cohesion increased until $6 \%$ of contaminating matter and for $9 \%$, the friction angle and apparent cohesion both decreased. This indicates that, although for cohesive soils the contaminating matter can change the shear strength parameters of soil (friction angle and cohesion), but the amount of contaminating matter is important in changing these soil parameters. Khosravi et al. [21] carried out direct shear tests on samples of a cohesive soil contaminated with different amounts of gasoline. The results showed that the friction angle increased and the apparent cohesion decreased in comparison with the natural soil. Ghadyani et al. [22] investigated the effect of gasoline and kerosene as contaminating matters on the mechanical properties of two different clay soils. They reported that the compaction behavior of the two soils improved after contamination with gasoline and kerosene but the variations of the strength of them did not follow the same trend. It is observed that the soils that were used by Singh et al. [11], Khosravi et al. [21] and Ghadyani et al. [22] were cohesive but the results did not follow the same trend. It can be said that for the same cohesive soil, the type of contaminating matter is important in changing the shearing parameters of the contaminated soil. A review of the literature shows that the previous research works have not considered the long term behavior of contaminated soils under undrained conditions, except for research work that was conducted by Estabragh et al. [23]. 
They studied the mechanical properties of a clay soil contaminated with glycerol and ethanol through triaxial tests. They concluded that the friction angle is increased with increasing the percent of contaminating matter and the amount of increase is a function of the type of contaminant. This paper focuses on the study of shear behavior of contaminated cohesive soils in the framework of elasto-plasticity.

\section{2- Aim of this study}

A review of the literature shows that the majority of experimental tests have been conducted on granular soils and the results of (particularly triaxial) tests on the study of the effect of petroleum-contaminated cohesive soils are relatively rare, particularly in term of critical state model parameters. On the other hand, this kind of soil may be used in construction projects as a cost-effective alternative to remediation or replacement with clean soil. Therefore, investigation into the mechanical and physical properties of cohesive soils contaminated with petroleum products is needed when such soils are used in civil engineering practice. This is due to the environmental concerns relating to the groundwater pollution and other possible effects on the environment.

In this work the long-term behaviour of a clay soil contaminated with MEG is studied through a program of one dimensional consolidation and consolidated undrained (CU) triaxial tests on natural and contaminated soil samples. The critical state condition and Roscoe surface for the cohesive soil contaminated with MEG is studied and a comparison is made with soil samples saturated by water as pore fluid.

\section{3- Material}

The basic material that was used in this work was a cohesive soil and Mono Ethylene Glycol (MEG) as the contaminating fluid.

\section{3-1- Soil}


The grounds around the airports in Tehran, Iran, are composed of a clay soil. The run off of the airport that may contain MEG, has entered these grounds and affected their behavior. For this reason, the clay soil was selected in this study. Tables 1 and 2 show the physical and chemical properties of the soil. The soil can be classified as clay with low plasticity (CL) according to the Unified Soil Classification System (USCS). The results of standard compaction tests showed that the maximum dry unit weight and optimum water content were $17.0 \mathrm{kN} / \mathrm{m}^{3}$ and $17.0 \%$ respectively. XRD (X-ray diffraction) tests were conducted on samples of the soil and the results are shown in Fig.1. As shown in Fig.1a the minerals of the soil include quartz, calcite, feldspar $(\mathrm{Na}, \mathrm{Ca})$ and feldspar $(\mathrm{K})$. The results also show that the clay minerals of the soil are illite, chlorite and montmorillonite (Fig.1b). Since the selected soil is composed of silt and clay, its sensitivity index is in the range of 0.6-0.9 (as suggested by Fang [1]). This indicates its high potential for interaction with MEG.

\section{3-2- Mono Ethylene Glycol (MEG)}

Mono Ethylene Glycol (MEG) is an organic compound with chemical formula $\mathrm{C}_{2} \mathrm{H}_{6} \mathrm{O}_{2}$. It is produced from ethylene via intermediate ethylene oxide. It is completely miscible in water. The dielectric constant, absolute viscosity and mass density of MEG at $25^{\circ} \mathrm{C}$ are $37.7,1631(\mathrm{cp})$ and $1132.2\left(\mathrm{Kg} / \mathrm{m}^{3}\right)$ respectively according to the information that was provided by the manufacturer. It breaks down in air in about ten days, and in water or soil in a few weeks. It enters the environment through the dispersal of ethylene glycol-containing products, especially at airports where it is used in deicing agents for runways and airplanes. Dobson [24] indicated that the existence of MEG in run off of airport is harmful and may cause serious environmental damage. When MEG enters the soil it has little or no capacity to bind to the particles. It is mobile in soil and penetrates to underground water (Lokke [25]). The spread of MEG 
to the environment can occur by leakage from the relevant plants to surface water and soil (Grabinska and Loniewska [26], Flathman et al. [27] and Sils and Blakeslee [28]) and also leakage from coils of heating pump (Lokke [25]). It can spread following a spill on surface water or soil. Solutions with 10, 25 and $40 \%$ concentration of MEG were used in this work and their properties are shown in Table.3.

\section{4- Sample Preparation}

The slurry technique was used for preparing the samples with pure water or different concentrations of MEG as the pore fluid. This technique of sample preparation allows to produce homogenous and reproducible samples with near saturation condition. It also simulates the long-term condition for the samples and allows uniform distribution of pore fluid throughout the sample. Ratnaweera and Meegoda ([3]) state that this method of sample preparation also prevents from the formation of a metastable soil structure. This method of preparing samples for contaminated soil was used by researchers such as [3], [9] and [12]. The required amount of soil was mixed with distilled water or MEG solution with desired concentration to bring the water content of the soil above the liquid limit to form a slurry. The resultant slurry was mixed by hand steer for about one hour until a smooth liquid resulted. A number of cylindrical

tubes (so called consolidation tubes) with $150 \mathrm{~mm}$ diameter and $300 \mathrm{~mm}$ height were filled with the slurry for consolidation ([13]). The mixture (soil and MEG solution) was covered with a nylon wrap and kept for about 7 days to reach an ionic equilibrium condition. The consolidation procedure was done by applying a vertical load by a hydraulic jack to maximum pressure of $80 \mathrm{kPa}$. Drainage was allowed from the top and bottom of the consolidation tube. This stage lasted nearly 7 days. After consolidation the samples were extruded into conventional consolidation mould and also into $38 \mathrm{~mm}$ diameter thin walled stainless steel tube for triaxial tests. The 
samples were waxed at both ends to keep the initial condition. They were then stored in a controlled temperature of $20^{\circ} \mathrm{C}$ before used for main tests.

\section{5- Testing program}

One dimensional consolidation and consolidated undrained (CU) triaxial tests were performed on the prepared samples. The consolidation behaviour of soil samples with water and different percentages of MEG was investigated through a number of standard oedometer tests under zero lateral strain. For studying the effect of MEG on the shear strength of soil a series of consolidated undrained (CU) triaxial tests were carried out on samples with pure water and water with different percentages $(10,25$ and $40 \%$ ) of MEG as pore fluid. Each sample was set up in the triaxial apparatus according to the method proposed by Head [29] for performing triaxial tests. The back pressure line was filled with the MEG solution that was used for preparing the samples. It was connected to the bottom of the sample and the liquid was flowed into the sample. The pressure of the liquid entering the sample (back pressure) was set at $50 \mathrm{kPa}$ and the sample was kept under this back pressure for about 24 hours. Then the value of B (Bishop's pore pressure parameter) was measured. The value of B was generally more than $95 \%$ that showed full saturation of the sample. Each sample was isotropically consolidated to a confining pressure in the range from 200 to $400 \mathrm{kPa}$. After consolidation, shearing was performed on the samples under constant cell pressures of 200,300 and $400 \mathrm{kPa}$ at a constant rate of axial strain. An axial deformation rate of $7 \mathrm{~mm} / \mathrm{h}$ was selected giving a strain rate of $0.15 \%$ per minute as suggested by Smith and Smith [30]. The slow rate was chosen to ensure the equilibrium of pore water pressure throughout the sample during the test. The CU test also allowed the pore water pressure response of the soil samples to be studied during the tests. Majority of the tests were repeated three times and their obtained results 
were compared with each other. Then the average of the results was considered as the final result.

\section{6- Results}

The results of one dimensional consolidation tests for pure water and water with different percents of MEG as pore fluid are shown in Fig.2. In this figure the results are presented as the variation of specific volume $(v)$ with $L n p^{\prime}$ where $p^{\prime}$ is the applied pressure on the sample. The results show that the specific volume is decreased with increasing the applied pressure. It is seen from this figure that the position of consolidation curves is in the order of concentration of pore fluid; with the curves corresponding to $0 \%$ and $40 \%$ MEG at top and bottom respectively and the curves moving downwards with increasing the MEG content. It is also observed from this figure (Fig.2) that at a given applied pressure the reduction of specific volume is not the same for all samples with different pore fluids; for example, at $20 \mathrm{kPa}$ pressure the specific volume for the sample with water as pore fluid is 2.052 but for 10,25 and 40\% MEG (at the same applied pressure) it is changed to 1.86, 1.77 and 1.69 respectively. It is resulted that the reduction of specific volume at constant pressure is a function of MEG concentration. By increasing the load the soil starts to yield at some point and normal consolidation line is formed. The intersection of the two linear segments of the consolidation curve is used for determination of the preconsolidation pressure as used by Cui and Delage [31] and Estabragh and Javadi [32].

A total of 12 consolidated undrained (CU) triaxial tests were conducted on samples with water and MEG solutions with concentrations of 10, 25 and $40 \%$. The triaxial tests were conducted at three different cell pressures of 200, 300 and $400 \mathrm{kPa}$. The selection of cell pressures of 200,300 and $400 \mathrm{kPa}$ was based on the locations of these points on the normal consolidation line (NCL). A difference of $100 \mathrm{kPa}$ between 
the cell pressures was chosen to compare the results for different points on the NCL. Figs.3a and $3 \mathrm{~b}$ show the variations of $q / p^{\prime}$ and $u_{w} / p^{\prime}$ against axial strain for samples with different concentrations of MEG at constant cell pressures of 200, 300 and 400 $\mathrm{kPa}$. These curves are similar to the variations of deviator stress and pore fluid pressure with axial strain. This method of presenting data was suggested by Toll and Ong [33] for determination of critical state condition in the case of shear band and nonhomogenous deformation. They stated that it is always difficult to determine the true critical state condition for bonded or dense materials as they often fail through the development of distinct shear surface where nonhomogenous deformation will affect the results. They therefore assumed that the ultimate or constant value of $q$ / $p^{\prime}$ defines the critical stress condition. As shown in this figure the ratio of $q / p^{\prime}$ and $u_{w} / p^{\prime}$ is increased with increasing the cell pressure for a given pore fluid and at constant cell pressure they are increased with increasing the concentration of MEG. It is seen from this figure that at the axial strain of about $15 \%$ these values (i.e. $q / p^{\prime}$ and $u_{w} / p^{\prime}$ ) for natural soil and contaminated soil reached constant values that define the critical state condition.

The elastic modulus (E) for samples with different concentrations of MEG was calculated from the initial slope of the stress-strain curves. The variations of elastic modulus with cell pressure and MEG concentration are shown in Fig.4. As shown in this figure, the elastic modulus increased with increasing the cell pressure. At a constant cell pressure, the elastic modulus increased with increasing the concentration of MEG; so for water as pore fluid the stiffness is lower and it increases with increasing the MEG concentration.

\section{7- Discussion}


The results obtained in this work can be explained with the aide of clay structure and behaviour of pore fluid. Structure of a soil can be defined as the geometric arrangement of soil particles. The effect of pore fluid on the soil structure can be divided into two groups of mechanical and physicochemical interactions. Mechanical interactions occur when solid particles rotate and translate at contacts. The physicochemical interactions occur when mineral particles interact with pore fluid and make diffuse double layer around the particles. In cohesive soils physicochemical factors are more important than mechanical factors while in granular soils the effect of mechanical factors is dominant. The surfaces of clay minerals carry negative charges mainly as a result of the isomorphic substitution or due to disassociation of hydroxyl. When water is added to the dry particle, the adsorbed cations will try to diffuse away from the surface in order to equalize concentrations. However, their movement will be restricted by the surface's negative electric field and this will result in the formation of a micelle of ions in suspension next to the particle surface. A hydrated clay particle will, therefore, have an associated micelle in which the adsorbed ions are scattered in space and separated from the particle surface. Mitchell [6] stated that the charged particle surface and the ion micelle form an electrostatic system known as the diffused double layer (DDL). The changes in the thickness of this layer produce different soil structures. When this layer is shrunk flocculated structure is formed and by increasing the thickness of DDL dispersed structure is formed. The thickness of DDL depends on many factors such as surface charge density, temperature, ion type, concentration of pore fluid, viscosity and dielectric constant of pore fluid.

The dielectric constant is reduced with increasing the concentration of MEG which leads to reduction of DDL. Therefore, the degree of flocculation is different for the 
samples with different concentrations of MEG and DDL is decreased with increasing the MEG concentration. The flocculation results in increase in the contact between particles which increases the resistance of particle against applied load. However, the experimental results of consolidation tests show the opposite effect; by increasing the concentration of MEG the compressibility is reduced at constant load. It is generally known that the viscosity of pore fluid plays an important role in the compression of the samples [13]. The viscosity of pore fluid can facilitate lubrication at particle contact and reduce the voids between particles and make a closer packing. The results of consolidation tests (Fig.2) are in agreement with this assumption. The viscosity of MEG with $40 \%$ concentration is more than that of MEG with $10 \%$ concentration. This result in greater compression for the samples contaminated with $40 \%$ concentration of MEG.

The consolidation behaviour of the clay soil with pure water and water with different percentages of MEG was studied through one dimensional consolidation tests. The results show that the preconsolidation pressure is increased with increasing the percentage of MEG (see Fig.5). The variation of $\lambda$ (slope of normal consolidation line) with MEG content is shown in Fig.6. It is observed that the value of $\lambda$ is decreased with increasing the concentration of MEG solution. Figs. 5 and 6 show the variations of preconsolidation pressure and compression index of soil at different concentrations of MEG. As shown in these figures, the preconsolidation pressure is increased and compression index is decreased with increasing the concentration of MEG. The compressibility of a soil is indicated by compression index. A higher value of compression index implies a higher compressibility. The value of this index is dependent on the dielectric constant of pore fluid. According to Table 3 dielectric constant decreases with increasing the concentration of MEG. This leads to decrease 
in thickness of the diffuse double-layer. As the values of compression index $\lambda$ of the soil decreases, the soil becomes stiffer and hence, reduction in compression is observed (Fig.6). All samples were prepared by the slurry method and as they were saturated, the surface tension of pore fluid would not have any effect on the formation of the soil structure. Therefore, the main factors that influence the structure of clay soil are density and viscosity of pore fluid. By increasing the concentration of MEG the density is increased while the viscosity does not change significantly. Therefore, influence of density on formation of the soil structure may prevent $\lambda$ from increasing. Preconsolidation pressure is increased with increasing concentration of MEG (Fig.5). The results in Fig.2 show that the by increasing the concentration of MEG the compressibility of samples is reduced and their density is increased. This can be attributed to the structure of soil formed during sample preparation. Therefore, the preconsolidation pressure is increased (Fig.5) by increasing the density of the soil due to increase in the concentration of MEG. It is resulted that adding MEG reduces the compressibility and increases the stiffness of the soil. Therefore, the variation of compressibility and stiffness of soil is a function of MEG concentration.

The triaxial tests on the soil samples with water or MEG solutions as pore fluid usually terminated at $20 \%$ axial strain. At this stage the samples were bulging and there was no evidence of failure. The results (Fig.3) show that the variation of $q / p^{\prime}$ against strain is markedly affected by MEG. The results show evidence of hardening behavior with increasing the concentration of MEG in pore fluid. This also resulted an increase in undrained shear strength and increase in elastic modulus (as shown in Fig.4). The value of hardening is increased with increasing the concentration of MEG and the threshold for different samples is nearly at strain of $7 \%$. Comparing the results at different cell pressures and constant concentration of MEG shows that 
the cell pressure is also an important factor in increasing hardening when this cell pressure is a pressure on normal consolidation line. Therefore, the selection of pressure on normal consolidation line is important for hardening of the sample. The increasing of hardening is observed from conducting tests on samples that were contaminated with different concentrations of MEG. A basic idea for the formulation of the Hardening-Soil model is the hyperbolic relationship between the vertical strain and the deviatoric stress in triaxial compression test. When a soil sample is subjected to primary deviatoric loading, the soil shows a decreasing stiffness and simultaneously irreversible plastic strains develop. Therefore, the value of plastic strain $\left(\varepsilon^{p}\right)$ is a measure of hardening and is defined by the following relationship that was suggested by [34].

$$
d \varepsilon^{p}=\frac{\lambda-k}{M v p^{\prime}}\left[\left(M-\frac{q}{p^{\prime}}\right) d p^{\prime}+d q\right]
$$

where $\lambda, k$ are slopes of normal consolidation and swelling (unloading) lines respectively, $v$ is specific volume and $\mathrm{M}$ is the slope of critical state line in $q$ $: p^{\prime}$ space. The results show that these parameters are functions of MEG concentration. Therefore, they are not constant in the above relationship and are changed with concentration of MEG and different concentrations of MEG lead to different values of $\varepsilon^{p}$ and hardening.

The initial slopes of the stress-strain curves of the contaminated soil are steeper than the sample with water as pore fluid and the increase of elastic modulus is a function of MEG concentration. It can be concluded that changes in concentration of MEG could have a significant effect on the mechanical behavior of the soil; and the strength and stiffness of soil are increased with increasing the concentration of MEG. The results indicate that there is a direct relationship between the strength and percent of MEG, at 
least in the range of the experimental tests that were conducted in this study. It can be said that the amount of increase in strength at constant confining pressure depends on the compressibility of samples before beginning of the shear stage. As shown in Fig.2, the compressibility of the samples is reduced by increasing the percentage of MEG. The compressibility of water and fluids with different concentrations of MEG is low and the applied load causes increase in the pore fluid pressure. As it mentioned above, increasing the concentration of MEG leads to the formation of coarse particles the compressibility of which is decreased in comparison with the soil with fine particles. The formation of coarse particles is dependent on the concentration of MEG. During loading the pressure of pore fluid is increased. The higher the degree of flocculation, the coarser the soil and the higher the pore fluid pressure. Therefore, the strength of the samples with $40 \%$ MEG is more than the samples with 25,10 or $0 \%$ MEG. The pore fluid pressure increased steadily during shearing and with increasing the percentage of MEG and confining pressure. It can be concluded that MEG has a significant effect on the generation of pore fluid pressure within the soil during the $\mathrm{CU}$ test; so, the excess pore pressure is higher for contaminated soil than the natural soil at a given confining pressure.

The critical state model developed for saturated soils is defined in terms of the mean net stress $p^{\prime}$, deviator stress $q$ and specific volume $v$ ([35]). For the simplified axisymmetric conditions of triaxial tests $\left(\sigma_{2}=\sigma_{3}\right)$, these state variables are defined as:

$$
\begin{aligned}
& p^{\prime}=\left(\frac{\sigma_{1}+2 \sigma_{3}}{3}\right)-u_{w} \\
& q=\left(\sigma_{1}-\sigma_{3}\right) \\
& v=1+\mathrm{e}
\end{aligned}
$$


where $\sigma_{1}, \sigma_{3}$ are axial and radial stress and e is void ratio. If a saturated soil is sheared, it will finally reach a critical state where shearing can continue without any further changes in $q, p^{\prime}$ and $v$. The specific volume of a soil at an isotropic normally consolidated state is linearly related to the logarithm of $p^{\prime}$. The deviator stress will be zero when the soil is under isotropic conditions. Therefore, the isotropic normal consolidation line is defined by the following equations:

$$
\begin{aligned}
& q=0 \\
& v=N-\lambda L n p^{\prime}
\end{aligned}
$$

where $N$ is the specific volume of the soil when $p^{\prime}$ is equal to $1 \mathrm{kPa}$ and $\lambda$ is the compression index. When soil is sheared it ultimately reaches a critical state. These critical states lie on a unique line in $q, p^{\prime}, v$ space. The critical state line is defined by the following equations:

$$
\begin{aligned}
& q=M p^{\prime} \\
& v=\Gamma-\lambda L n p^{\prime}
\end{aligned}
$$

where $\Gamma$ and $M$ are additional soil constants.

Roscoe et al. [36] examined saturated soil behaviour in a generalised elasto-plastic model. Undrained and drained tests were conducted on isotropically normally consolidated saturated soils. The results were plotted in $q, p^{\prime}, v$ space which showed the state boundary surface or Roscoe surface (a surface connecting the normal compression line to the critical state line). When the soil state lies inside the state boundary surface it behaves elastically. The elastic volume change behaviour can be modelled on elastic wall having the equation:

$$
v=v_{k}-k L n p^{\prime}
$$


where $k$ is a soil constant and $v_{k}$ is specific volume when the soil is unloaded to $p^{\prime}=$ $1 \mathrm{kPa}$. The behaviour of the soil on the state boundary surface is elasto-plastic with the intersection of the relevant elastic wall and state boundary surface defining a yield curve. Yielding of soil causes plastic volume changes and the yield curve expands outwards. The amount of expansion of the yield curve is dependent on the plastic volume change which takes place during the application of load.

The stress-strain results show that, in general, after axial strain of $15 \%$ by increasing the axial strain there is no change in the value of deviator stress. During triaxial tests when shearing continues indefinitely without changes in volume or effective stresses, this condition of perfect plasticity is known as critical state ([37]). Therefore, the strain of $15 \%$ was considered as critical state condition.

Table 4 shows the values of $\varphi$ and $\varphi^{\prime}$ for the samples with water and MEG solutions as pore water. For the soil with water as pore water the values of friction angles $(\varphi$ and $\varphi^{\prime}$ ) in terms of total and effective stresses are $16.3^{\circ}$ and $20.54^{0}$ respectively (Table 4). For soil samples with $40 \%$ MEG as pore fluid they are changed to $20.8^{\circ}$ and $32.13^{0}$. The values of friction angle that were determined from Mohr circles are equal to the angles that were obtained at critical state. This is because the stresses due to $15 \%$ axial strain were used for drawing the Mohr circles and at this strain the samples were in critical state condition. The results of stresses and strains show that, in general, after axial strain of $15 \%$, by increasing the axial strain there is no change in the value of deviator stress. During triaxial tests when shearing continues indefinitely without changes in volume or effective stresses, this condition of perfect plasticity is known as critical state ([37]). Therefore, the strain of $15 \%$ was considered as critical state condition. The increase in the pore fluid pressure decreases the effective stress within the soil mass. Typical stress paths for soil samples with $10 \%$ MEG as pore 
fluid are shown in Fig.7 in the spaces of deviator stress, $q$ and effective mean net stress, $p$ ' or deviator stress and total mean stress, $p$. The horizontal distance between the effective stress and total stress shows the value of pore water pressure at the desired stress point. The total stress paths (TSP) are straight lines with slope of 3 vertical to 1 horizontal. Positive pore pressure was developed which caused the effective stress path (ESP) to rise to the left along a curved path. In general the shape of stress paths for soil samples with water as pore fluid or MEG solution as pore fluid indicates an increase in pore pressure with deformation. At the critical state the paths reached to the peak value where the samples continued plastic deformation with no change in applied stress or pore pressure. Fig. 8 shows typical effective stress paths and failure envelop for soil samples with 25 and $40 \%$ MEG as pore fluid. The failure envelop for soil samples with $40 \%$ MEG solution is located above the failure envelop of soil with $25 \%$ MEG. This shows that increasing the percent of MEG causes increase in strength of soil samples. This increase in strength is due to the interaction of MEG with soil. The increase in strength results from a combination of increase in the peak deviator stress, as well as the decrease in effective stress (due to increase in pore pressure) caused by the MEG leading to a greater shift (to the left) in $p^{\prime}$ value. The values of $q$ at axial strain of $15 \%$ were assumed as critical state condition for natural and contaminated soil. Then the critical state lines were established for each condition of pore fluid. In the critical state theory, the critical state line is defined as $q=M p^{\prime}$ in the $q: p^{\prime}$ space, i.e., the variations of $q$ and $p^{\prime}$ are located on a straight line. For achieving this condition more data is needed. In this work, since the data were limited because of limiting time and due to the time limit (as preparing samples by the slurry method and testing was time demanding), the above assumption was 
adopted and a straight line was fitted to the data for establishing the critical state line in this space.

Fig. 9 shows the critical state lines for the natural soil and the soil contaminated with different percentages of MEG. As shown in this figure the value of $M$ (slope of critical state line) is not the same for natural soil and soil contaminated with MEG. The value of $\mathrm{M}$ is greater for contaminated soil in comparison with natural soil. The values of $M$ in the space of $q$ and $p^{\prime}$ were found to be 0.80 for water as pore fluid and $1.04,1.15$ and 1.29 for 10,25 and $40 \%$ of MEG respectively. The results also show that the value of $\mathrm{M}$ is dependent on the concentration of MEG. Increasing concentration results in increase in the value of $M$. The friction angle that is produced from Mohr circles with the values that are calculated by using the value of $M$ according to the following equation are nearly the same.

$$
M=\frac{6 \sin \varphi^{\prime}}{3-\sin \varphi^{\prime}}
$$

Since consolidated undrained triaxial tests were conducted on the samples, therefore the volume (and specific volume) of the sample is constant during shearing in reaching to critical state condition. On the other hand, since the specific volume at a constant pressure on normal consolidation line is dependent on the concentration of MEG, hence the location of critical state line in the space of $q, p^{\prime}$ and $v, p^{\prime}$ is dependent on the concentration of MEG. For normally consolidated soil, all drained and undrained stress paths appear to lie on a three dimensional surface bounded by the critical state line at the top and normal consolidation line at the bottom. It can be shown that both sets of stress paths lie on this surface. This surface is called Roscoe surface or state boundary surface. The Hvorslev surface is another state boundary surface and links up with Roscoe surface at the critical state line. This surface is a 
straight line in the normalized space of $\frac{q}{p_{e}^{\prime}}: \frac{p}{p_{e}^{\prime}}$ where $p_{e}^{\prime}$ is the equivalent pressure and is defined as:

$$
p_{e}^{\prime}=\exp \left(\frac{N-v}{\lambda}\right)
$$

where $N, \lambda$ are the intercept (at $p^{\prime}=1 \mathrm{kPa}$ ) and slope of saturated virgin line and $v$ is specific volume. Based on the consolidation results and by considering the undrained test (constant value of $v$ during shearing) the value of $p_{e}^{\prime}$ was calculated for each test. The Roscoe surfaces were plotted in the normalised space of $\frac{q}{p_{e}^{\prime}}: \frac{p}{p_{e}^{\prime}}$ for natural soil and soil contaminated with different percents of MEG (see Fig.10). This figure shows that this surface is not same for natural and contaminated soils. The location of the Roscoe surface for the contaminated soil is dependent on the concentration of MEG.Therefore, it can be said that the size of the elastic region in the contaminated soil is larger than the natural

\section{8- Conclusion}

A number of experimental tests were carried out to determine the effect of MEG on the properties of a clay soil. MEG solutions with concentrations of $0,10,25$ and $40 \%$ were used in the experiments. The following conclusions can be drawn based on the test results.

1- Preconsolidation pressure is increased and $\lambda$ (slope of normal consolidation line) is decreased with increasing the percentage of MEG.

2- The strength and stiffness of soil are increased with increasing the MEG concentration and the hardening of stress-strain curves is a function of MEG percent. 3- The friction angle in term of total and effective stress is increased for MEG as pore 
fluid in comparison with water as pore fluid and the amount of the increase is a function of MEG concentration.

4- The slope of critical state line for contaminated soil is greater than natural soil. Its variations for contaminated soil are dependent on the percentage of MEG. Roscoe surface exists for contaminated soil and the shape of it is similar to natural soil. For contaminated soil its position in the $p: q: v$ space is dependent on the concentration of MEG. 


\section{References}

[1] H.Y. Fang, Introduction to Environmental Geotechnology (CRC Press, Boca Raton, FL.,1997).

[2] N.J. Meegoda and R.A. Rajapakse, "Short-term and long-term permeabilities of contaminated clay", J Environ Eng 119 no. 4 (July 1993): 725-743, https://doi.org/10.1061/(ASCE)0733-9372(1993)119:4(725)

[3] P. Ratnaweera and J.N. Meegoda, "Shear strength and stress-strain behaviour of contaminated soils", Geotech Test J 29, no. 2 (March 2006): 133-140, https://doi.org/10.1520/GTJ12686

[4] R.E. Olson and G. Mesri, "Mechanisms controlling compressibility of clays", $J$ Soil Mech Found Eng, 6, no.11 (January 1970): 1863-1878.

[5] F. Fernandez and R.B. Quigley, "Hydraulic conductivity of natural clays permeated with simple liquid hydrocarbons”, Can Geotech J 22 (May 1985): 205-214, https://doi.org/10.1139/t85-028

[6] J.K. Mitchell, Fundamentals of soil behavior, 2nd Ed., (Wiley, New York, USA., 1993).

[7] N.J. Meegoda and P. Ratnaweera, "Compressibility of contaminated fine-grained soils", Geotech Test J 17, no.1 (March 1994): 101-112, https://doi.org/10.1520/GTJ10078J

[8] A. Sridharan and K. Prakash, "Mechanism controlling the undrained shear strength behaviour of clays", Can Geotech J 36, no.6 (December 1999): 10301038, https://doi.org/10.1139/t99-071

[9] J. Chen, A. Anandarajah and H. Inyang, "Pore fluid properties and compressibility of kaolinite", J Geotech Geoenviron Eng 126, no. 9 (September 2000): 798807, https://doi.org/10.1061/(ASCE)1090-0241(2000)126:9(798) 
[10] J. Graham, K. Yuen, T.B. Goh, P. Janzen and V. Sivakumar, "Hydraulic conductivity and pore fluid chemistry in artificially weathered plastic clay", Eng Geol 60, no. 1-4 (June 2001): 69-81, https://doi.org/10.1016/S00137952(00)00090-9

[11] S.K. Singh, R.K. Srivastava and J. Siby, "Studies on soil contamination due to used motor oil and its remediation", Can Geotech J 46 (September 2009) 1077-1083, https://doi.org/10.1139/T09-047

[12] L.D. Di Matteo, F. Bigotti and R. Ricco, "Compressibility of kaolinitic clay contaminated by ethanol-gasoline blends", J Geotech Geoenviron Eng 137, no. 9 (September 2011) 846-849, https://doi.org/10.1061/(ASCE)GT.19435606.0000494

[13] A.R. Estabragh, I. Beytolahpour, M. Moradi and A.A. Javadi, "Consolidation behaviour of two fine-grained soils contaminated by glycerol and ethanol", $\begin{array}{llll}\text { Eng } & \text { Geol } & 178 & \text { 2014): }\end{array}$ https://doi.org/10.1016/j.enggeo.2014.05.017

[14] A. Sridharan and G.V. Rao," Mechanism controlling volume change of saturated clays and role of effective stress concept", Géotechnique 23 (September 1973): 359-371, https://doi.org/10.1680/geot.1973.23.3.359

[15] A. Sridharan and G. Rao, "Shear strength of saturated clays and the role of the effective stress concept", Géotechnique 2 (June 1979): 177-193, https://doi.org/10.1680/geot.1979.29.2.177

[16] E. Evgin and B.M. Das, "Mechanical behavior of an oil contaminated sand" (paper presentation, Mediterranean Conference on Environmental Technilogy, Cesm, Turkey, 25-27 May 1992). 
[17] H. Al-Sanad, W.K. Eid, and N. F. Ismael, "Geotechnical properties of oilcontaminated Kuwaiti Sand”, J Geotech Geoenviron Eng 121, no. 2 (May 1995): 407-412, https://doi.org/10.1061/(ASCE)0733-9410(1995)121:5(407)

[18] A.M. Ghaly, "Strength remediation of oil contaminated sands" (paper presentation, seventeenth International Conference on Soils Waste Technology and Management, Philadelphia, October 21-24, 2001).

[19] E.C. Shin, M.T. Omar, A.A. Tahmaz and B.M. Das, "Shear strength and hydraulic conductivity of oil contaminated sand" (paper presentation, fourth International Congress on environmental Geotechnics. Rio de Janeiro, Brazil, Balkema Publisher, 11-15 August, 2002).

[20] H. Rajabi and M. Sharifipour, "Effect of light crude oil contamination on small strain shear modulus of Firoozkooh sand”, Eur J Environ Civ En (in press), https://doi.org/10.1080/19648189.2017.1347525

[21] E. Khosravi, H. Ghasemzadeh, M.R. Sabour and H. Yazdani, “Geotechnical properties of gas oil-contaminated kaolinite”, Eng Geol 166 (November 2013): 11-16, https://doi.org/10.1016/j.enggeo.2013.08.004

[22] M. Ghadyani, A. Hamidi, and M. Hatambeigi, "Triaxial shear behavior of oil contaminated clay", Eur J Environ Civ En (in press), https://doi.org/10.1080/19648189.2016.1271359

[23] A.R. Estabragh, I. Beytolahpour, M. Moradi and A.A. Javadi, "Mechanical behavior of a clay soil contaminated with glycerol and ethanol”. Eur J Environ Civ En 20, no. 5 (May 2016): 503-519, https://doi.org/10.1080/19648189.2015.1047900 
[24] S. Dobson, "Ethylene Glycol: Environmental aspects" (Concise International Chemical Assessment Document 22, Institute of Terrestrial Ecology, Natural Environment Research Council, Huntingdon, United Kingdom, 2000).

[25] H. Lokke, "Leaching of ethylene glycol and ethanol in sub soils", Water Air Soil Poll 22 (May 1984): 373-387, https://doi.org/10.1007/BF00282608

[26] A. Grabinska-Loniewska, "Studies on the activated sludge bacteria participating in the biodegradation of methanol, formaldehyde and ethylene glycol: II. Utilization of various carbon and nitrogen compounds", Acta Microbio Pol Series B: Microbiologia Applicata. 6, no. 2 (1974): 83-88.

[27] P.E. Flathman, D.E. Jerger and L.S. Bottomley, "Remediation of contaminated ground water using biological techniques", Ground Water Monit R 9 (March 1989): 105-119, https://doi.org/10.1111/j.1745-6592.1989.tb01126.x

[28] R.D. Sills, and P.A. Blakeslee, "The environmental impact of deicers in airport storm water runoff. In: Chemical deicers and the environment” (Boca Raton, FL, Lewis Publishers, 1992), 323-340.

[29] K.H. Head, Manual of soil laboratory testing (Pentech Press, London, UK, 1986).

[30] G.N. Smith and I.G.N. Smith, Elements of soil mechanics (Blackwell Science Inc., Oxford, UK., 1990).

[31] Y.J. Cui and P. Delage," Yielding and plastic behaviour of an unsaturated compacted silt", Géotechnique 46, no.2 (June 1996): 291-331, https://doi.org/10.1680/geot.1996.46.2.291

[32] A.R. Estabragh and A.A. Javadi," Critical state for overconsolidation unsaturated silty soil", Can Geotech J 45, no.3 (March 2008): 408-420, https://doi.org/10.1139/T07-105 
[33] D.G. Toll, and B.H. Ong, "Critical state parameter for an unsaturated residual sandy clay", Géotechnique 53, no.1, (February 2003): 93-103, https://doi.org/10.1680/geot.2003.53.1.93

[34] J.H. Atkinson, and P.L. Bransby, The mechanics of soils (McGraw-Hill Book Company (UK) Limited, 1978).

[35] A.W. Schofield and C.P. Worth, Critical state soil mechanics (McGrow-Hill Publication, London, 1968).

[36] K.H. Roscoe, A.W. Schofield and C.P. Worth, "On the yielding of soils", Géotechnique $\quad 8, \quad$ no.1 (March 1958): 22-53, https://doi.org/10.1680/geot.1958.8.1.22

[37] D.M. Wood., Soil behaviour and critical state soil mechanics (Cambridge University Press, UK.1990). 


\section{List of Tables}

Table 1. Physical and mechanical properties of the used soil.

Table 2. Chemical composition of used soil

Table 3. Measured physical and chemical properties of pore fluids tested at $25^{\circ} \mathrm{C}$

Table 4. Mechanical parameters of natural and contaminated soil 
Table 1. Physical and mechanical properties of the used soil.

\begin{tabular}{lc}
\hline Properties & Value \\
\hline Specific gravity, $G_{s}$ & 2.72 \\
Grain-size distribution & \\
$\quad$ Sand (\%) & 23.0 \\
Silt $(\%)$ & 52.0 \\
Clay (\%) & 25.0 \\
Consistency limits & \\
Liquid limit, $L L(\%)$ & 47.0 \\
Plastic limit, PL $(\%)$ & 20.0 \\
$\quad$ Plasticity index, PI $(\%)$ & 27.0 \\
$\quad$ Shrinkage limit, SL $(\%)$ & 12.0 \\
USCS classification & $\mathrm{CL}$ \\
Compaction characteristics & \\
$\quad$ Optimum water content, $w_{\mathrm{opt}}(\%)$ & 17.0 \\
$\quad$ Maximum dry unit weight, $\gamma_{\mathrm{dmax}}\left(\mathrm{kN} / \mathrm{m}^{3}\right)$ & 17.0 \\
\hline
\end{tabular}


Table 2. Chemical composition of used soil

\begin{tabular}{|l|c|l|c|}
\hline $\begin{array}{l}\text { Chemical } \\
\text { component }\end{array}$ & Amount & $\begin{array}{l}\text { Chemical } \\
\text { component }\end{array}$ & Amount \\
\hline $\mathrm{pH}$ & 8.0 & $\mathrm{Mg}^{2+}(\mathrm{meq} / \mathrm{L})$ & 10.0 \\
\hline $\mathrm{EC}^{\mathrm{a}}(\mathrm{mmhos} / \mathrm{cm})$ & 10.74 & $\mathrm{Cl}^{-}(\mathrm{meq} / \mathrm{L})$ & 60.0 \\
\hline $\mathrm{Na}^{+}(\mathrm{meq} / \mathrm{L})$ & 114.0 & $\mathrm{CO}_{3}^{2-}(\mathrm{meq} / \mathrm{L})$ & 0.6 \\
\hline $\mathrm{K}^{+}(\mathrm{meq} / \mathrm{L})$ & 0.33 & $\mathrm{HCO}_{3}{ }^{-}(\mathrm{meq} / \mathrm{L})$ & 4.0 \\
\hline $\mathrm{Ca}^{2+}(\mathrm{meq} / \mathrm{L})$ & 24.0 & $\mathrm{SO}_{4}{ }^{2-}(\mathrm{meq} / \mathrm{L})$ & 83.0 \\
\hline $\mathrm{CO}_{3} \mathrm{Ca}(\%)$ & 10.2 & $\mathrm{O}^{2}{ }^{\mathrm{b}}(\%)$ & 0.11 \\
\hline
\end{tabular}

a-Electerical Conductivity

b- Organic content 
Table 3. Measured physical and chemical properties of pore fluids tested at $25^{\circ} \mathrm{C}$

\begin{tabular}{|c|c|c|c|c|}
\hline Fluid & $\begin{array}{c}\text { Mass density } \\
\mathrm{kg} / \mathrm{m}^{3}\end{array}$ & $\begin{array}{c}\text { Absolute } \\
\text { viscosity, } \mathrm{cp}^{1}\end{array}$ & $\begin{array}{c}\text { Dielectric } \\
\text { constant }\end{array}$ & $\begin{array}{c}\text { Electrical } \\
\text { conductivity } \\
\text { mmhos/cm }\end{array}$ \\
\hline Water & 997.05 & 0.894 & 78.5 & $8.40 \mathrm{e}-3$ \\
\hline MEG & 1132.2 & 1.61 & 37.7 & $6.42 \mathrm{e}-5$ \\
\hline $\begin{array}{c}10 \% \text { MEG } \\
\text { +water }\end{array}$ & 1077.40 & 1.18 & 65.40 & $8.40 \mathrm{e}-3$ \\
\hline $\begin{array}{c}25 \% \text { MEG } \\
\text { +water }\end{array}$ & 1097.80 & 1.073 & 71.30 & $8.40 \mathrm{e}-3$ \\
\hline $\begin{array}{c}40 \% \text { MEG } \\
\text { +water }\end{array}$ & 1117.50 & 0.966 & 75.8 & $8.40 \mathrm{e}-3$ \\
\hline
\end{tabular}

1. centipoises $=1$ milli pascal second

Table 4. Mechanical parameters of natural and contaminated soil

\begin{tabular}{|c|c|c|}
\hline Pore fluid & $\phi$ (degree) & $\phi^{\prime}$ (degree) \\
\hline Water & 16.3 & 20.54 \\
\hline $10 \%$ MEG +water & 18.21 & 26.12 \\
\hline $25 \%$ MEG +water & 18.92 & 28.66 \\
\hline $40 \%$ MEG +water & 20.80 & 32.13 \\
\hline
\end{tabular}




\section{List of Figures}

Fig.1. X-ray diffraction plots (a) minerals (b) clay mineral of soil

Fig.2. Consolidation curves for natural soil and soil contaminated with 10, 25 and $40 \%$ MEG

Fig.3. Variations the ratio of $q / p^{\prime}$ (a) and $u_{w} / p^{\prime}$ (b) against axial strain for different percents of MEG and different cell pressures

Fig.4. Variations of elastic modulus with different percents of MEG at constant cell pressure

Fig.5. Variations of preconsolidation pressure with different percentage of MEG

Fig.6. Variations of $\lambda$ with different percentage of MEG

Fig.7. Stress paths for with $10 \%$ MEG as pore fluid

Fig.8. Typical effective stress path for soil with 20 and $40 \%$ MEG as pore fluid

Fig.9. Critical state lines for soil samples with water and different percent of MEG as pore fluid

Fig. 10 . Roscoe surfaces were plotted in the normalized space of $\frac{q}{p_{e}^{\prime}}: \frac{p}{p_{e}^{\prime}}$ for natural soil and soil contaminated with different percents of MEG 


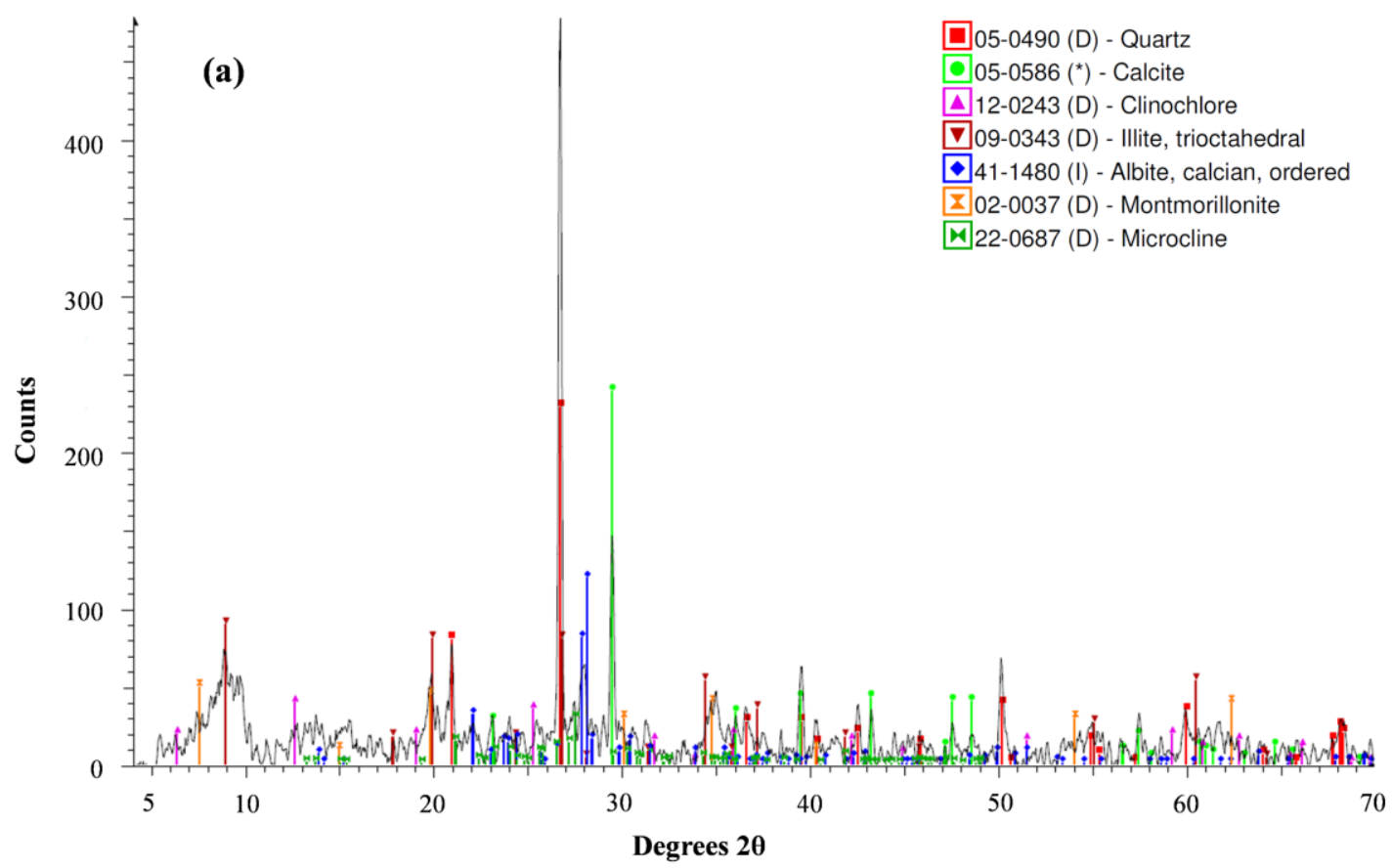

(a)

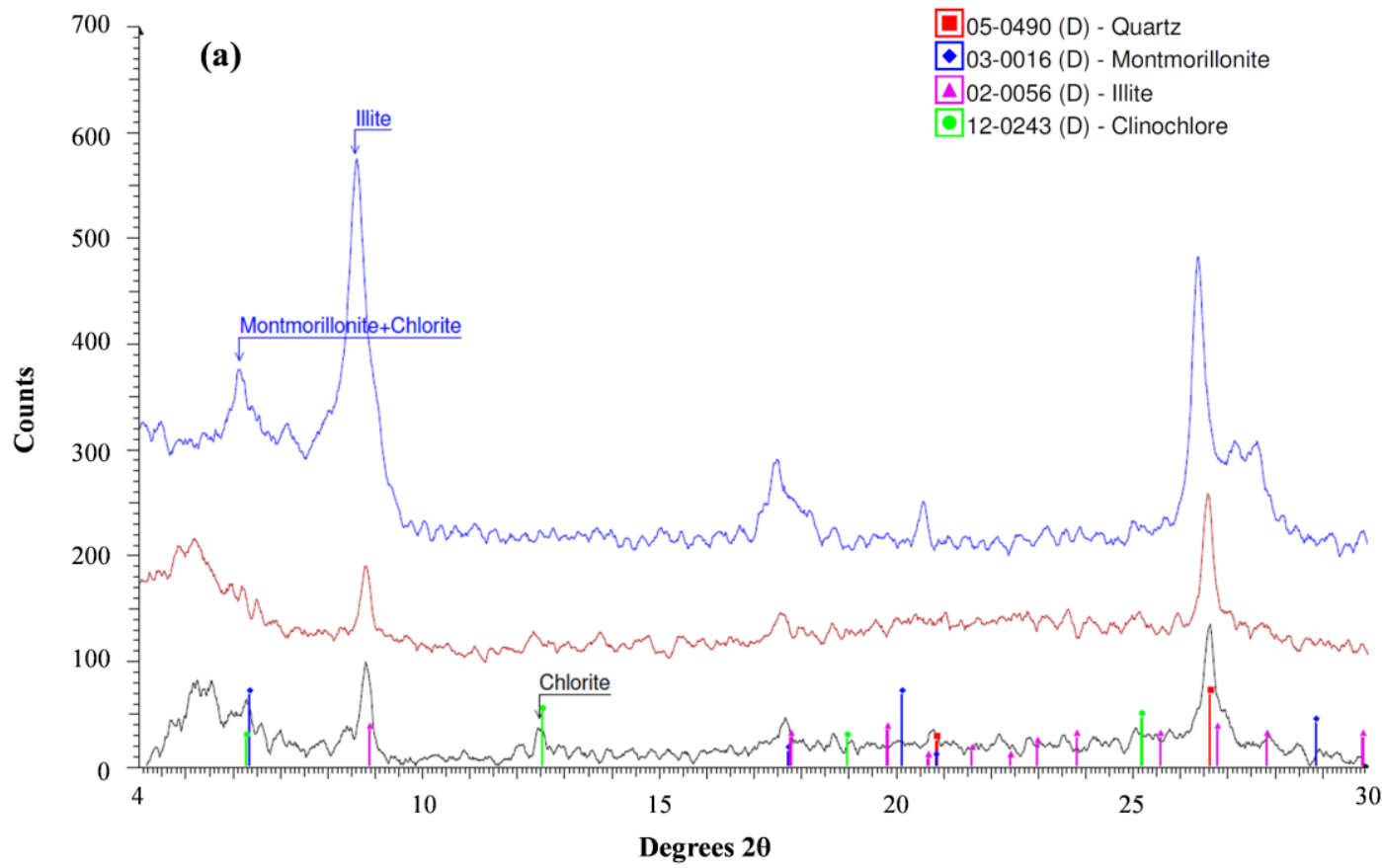

(b)

Fig.1. X-ray diffraction plots (a) minerals (b) clay mineral of soil 


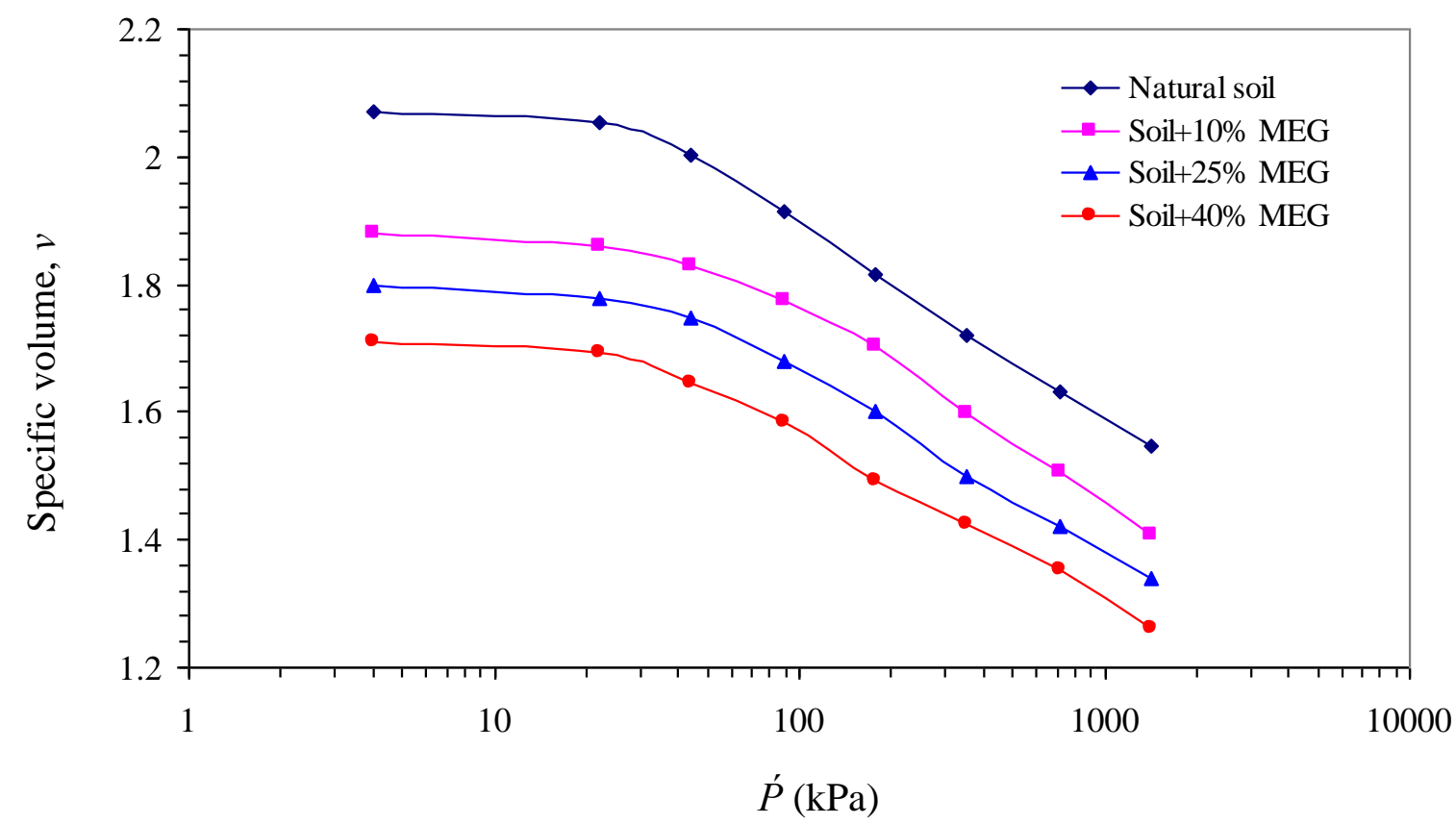

Fig.2. Consolidation curves for natural soil and soil contaminated with 10, 25 and $40 \%$ MEG 


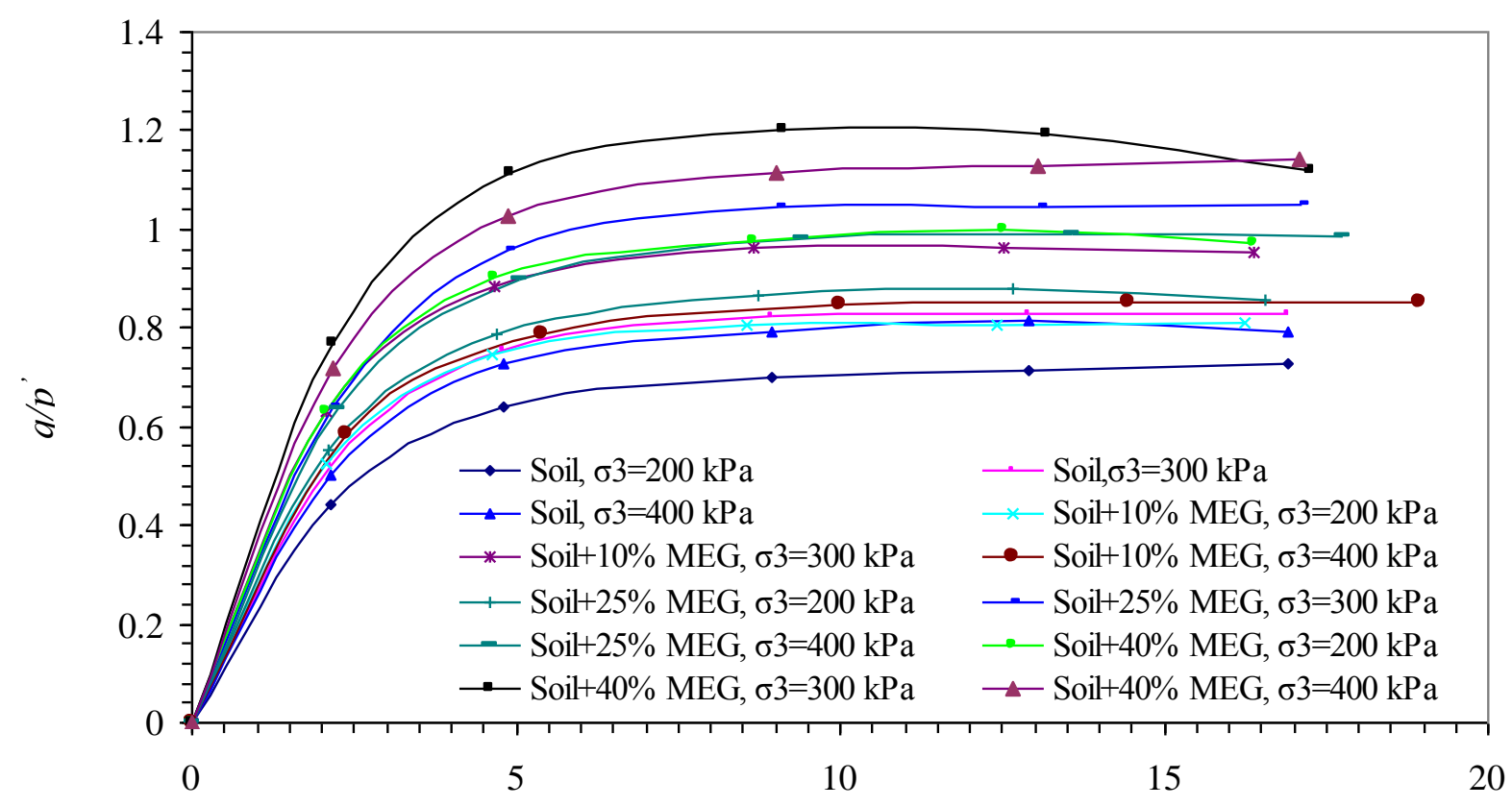

Axial strain, $\varepsilon_{a}(\%)$

(a)

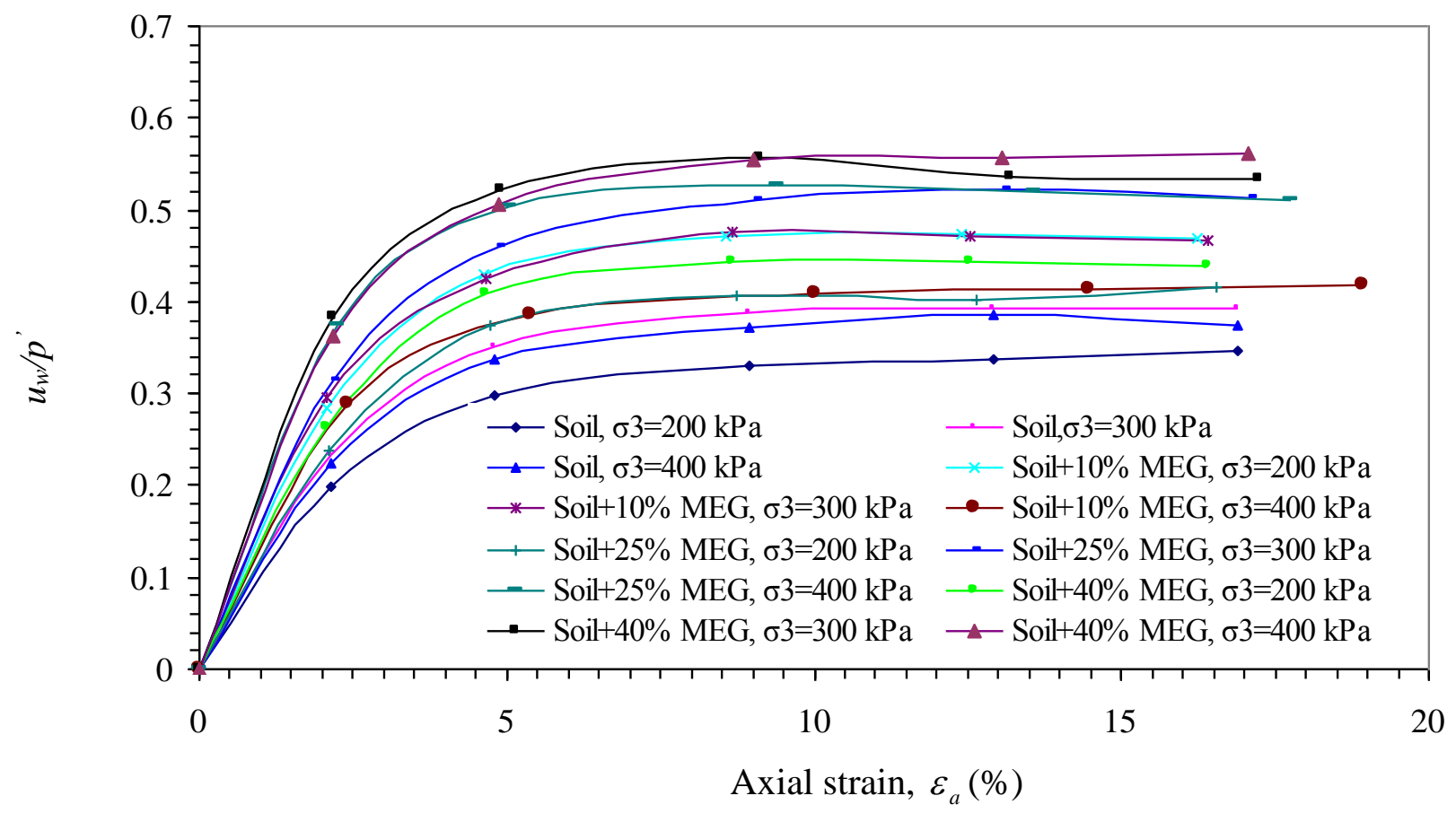

(b)

Fig.3. Variations the ratio of $q / p^{\prime}$ (a) and $u_{w} / p^{\prime}$ (b) against axial strain for different percents of MEG and different cell pressures 


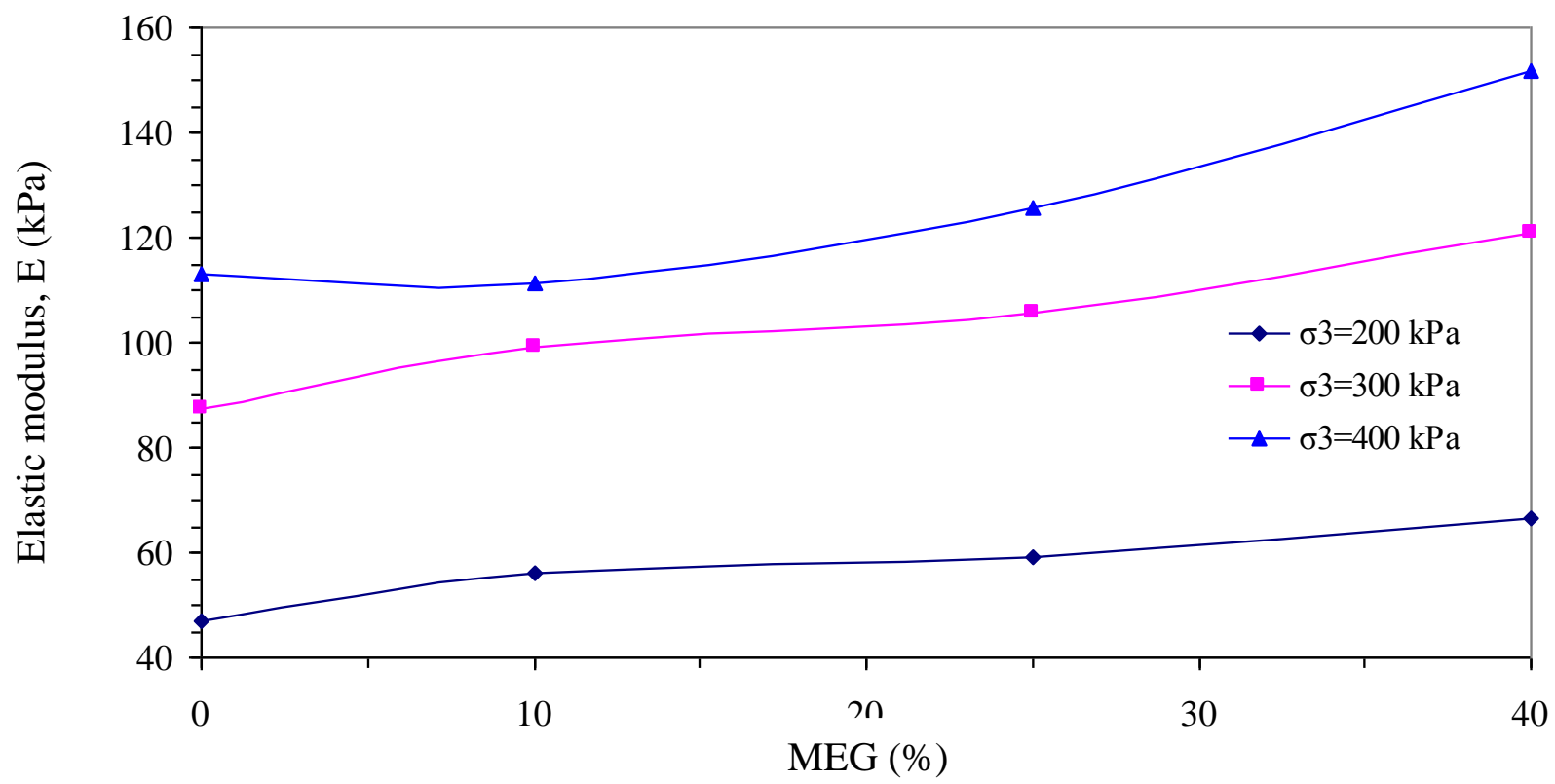

Fig.4. Variations of elastic modulus with different percents of MEG at constant cell pressure

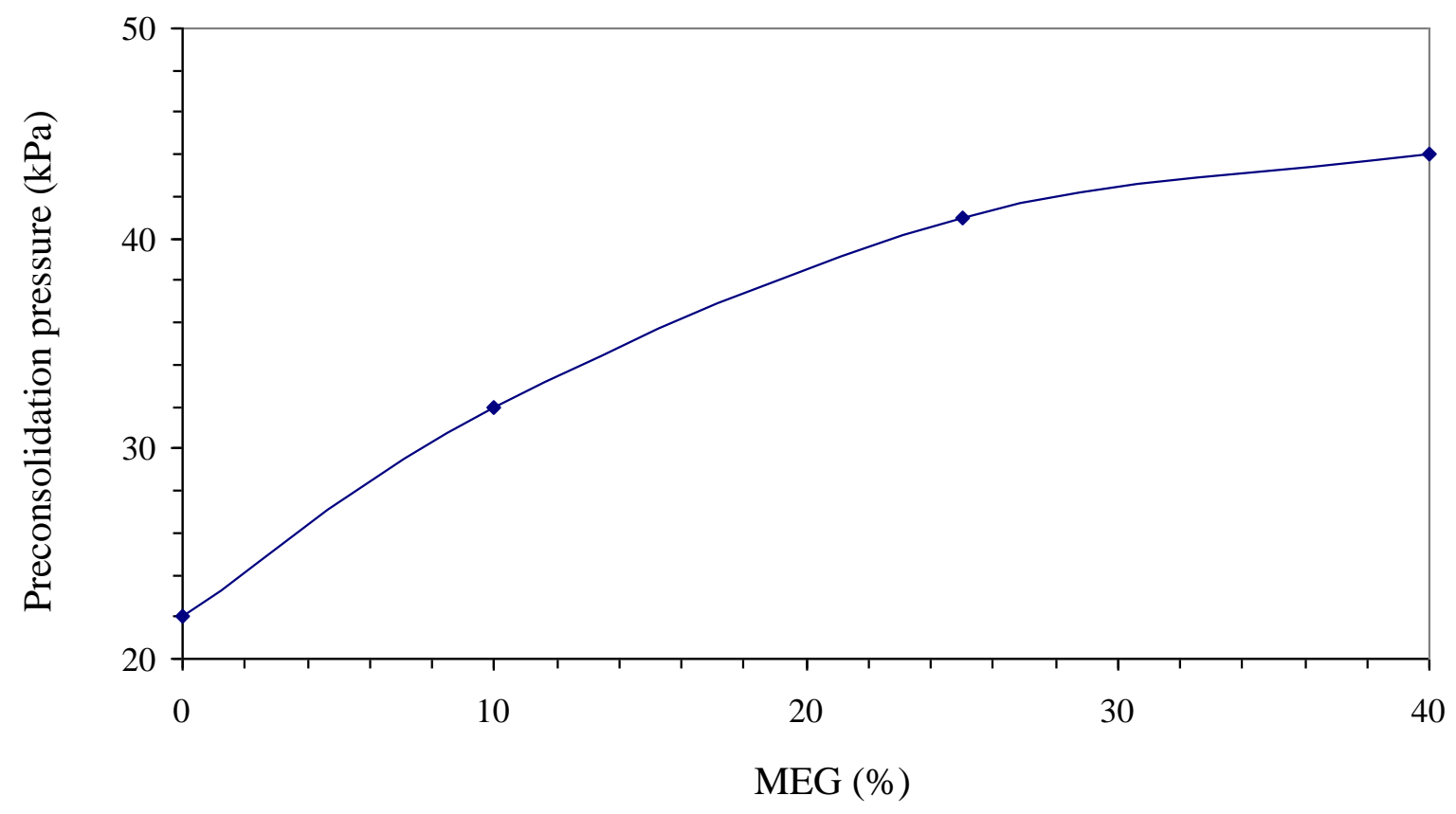

Fig.5. Variations of preconsolidation pressure with different percentage of MEG 


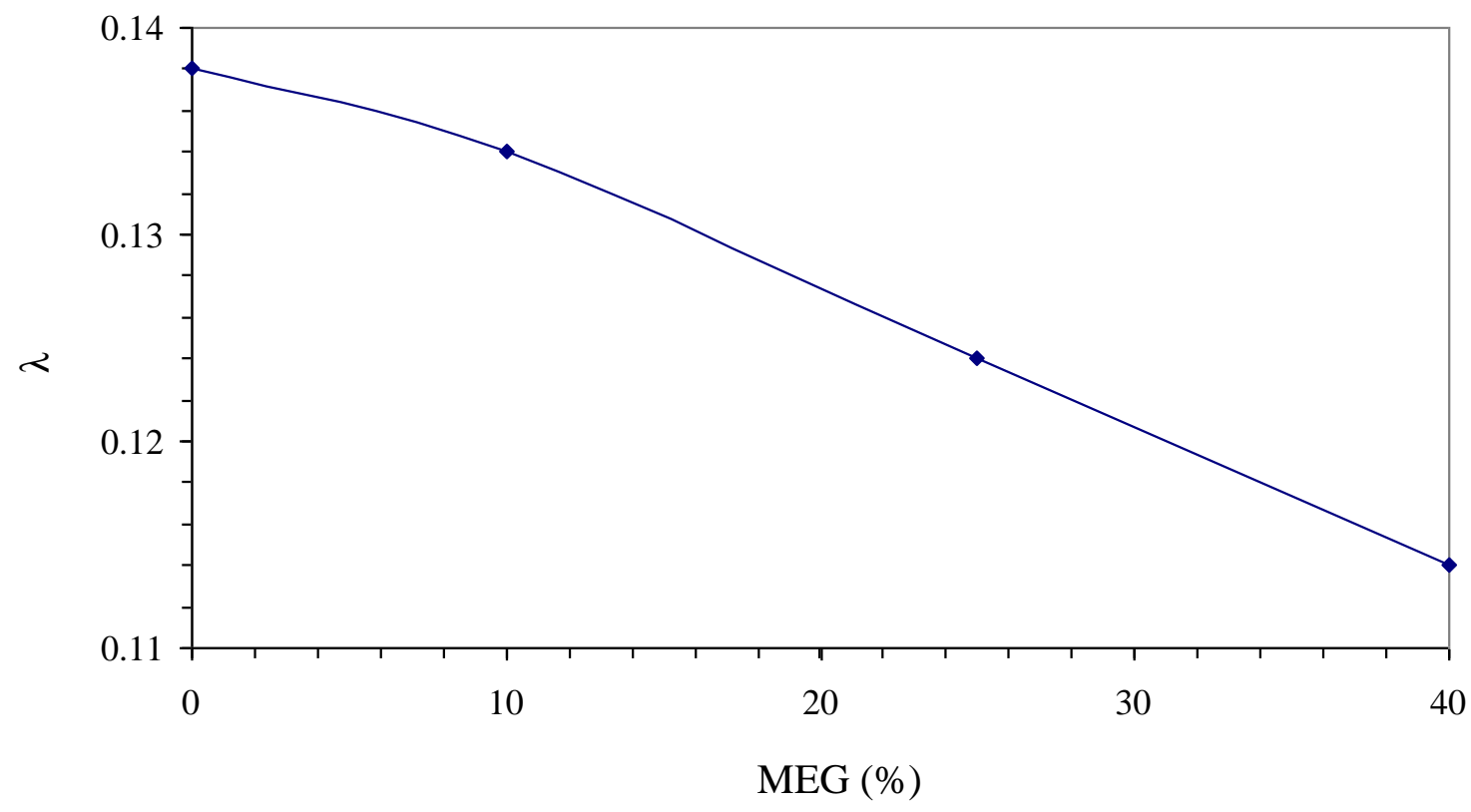

Fig.6. Variations of $\lambda$ with different percentage of MEG

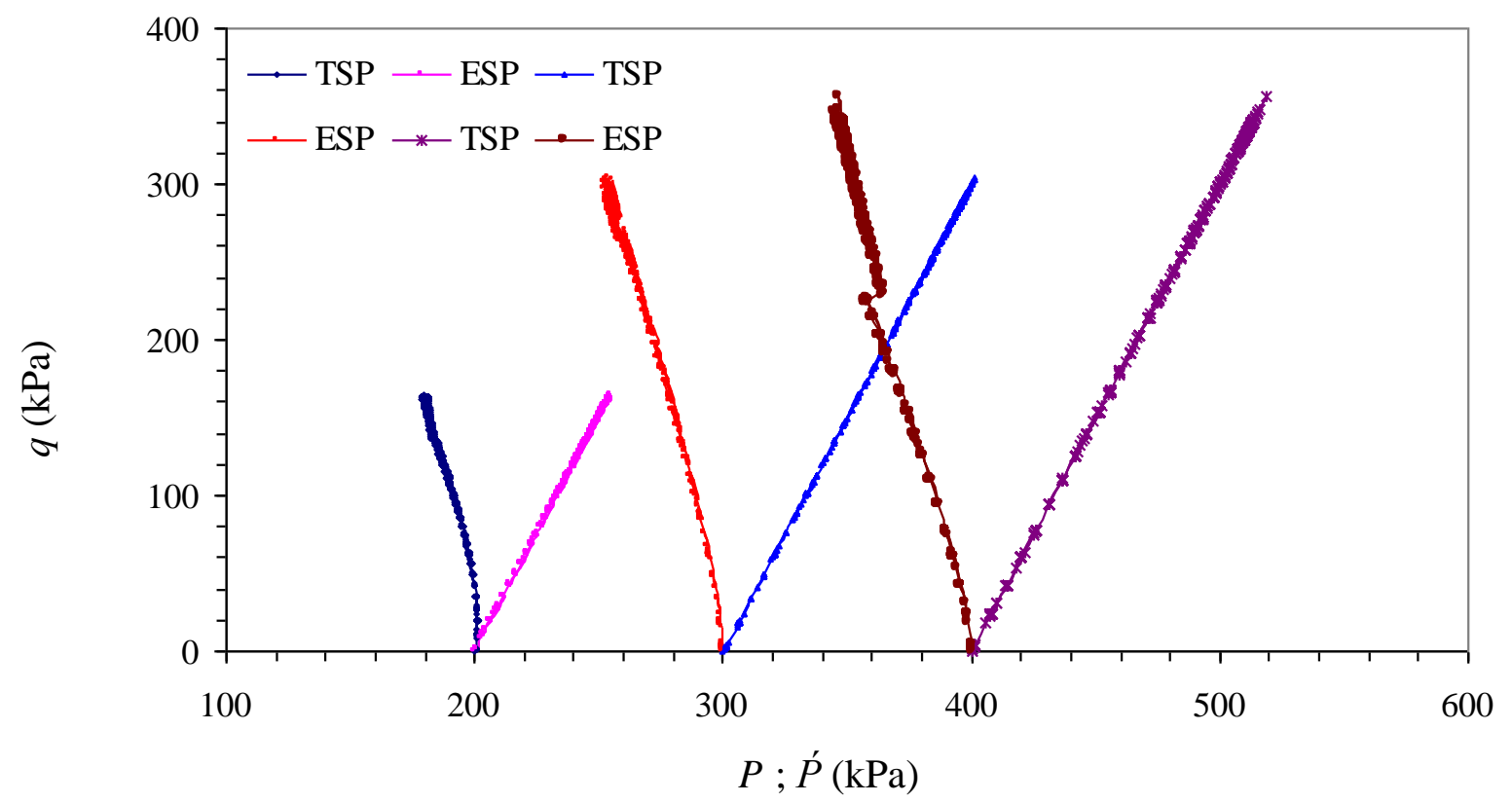

Fig.7. Stress paths for with $10 \%$ MEG as pore fluid 


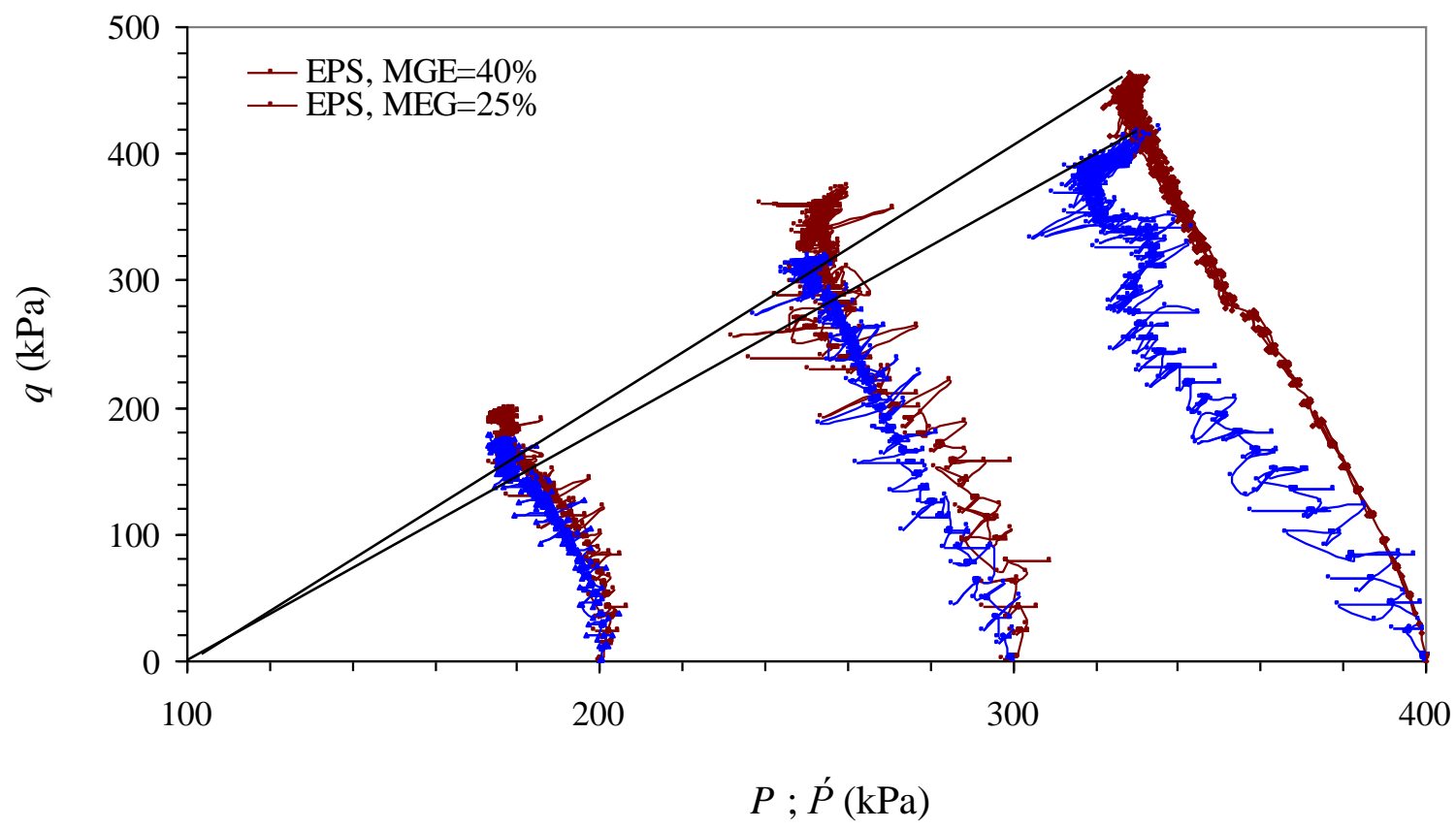

Fig.8. Typical effective stress path for soil with 20 and $40 \%$ MEG as pore fluid

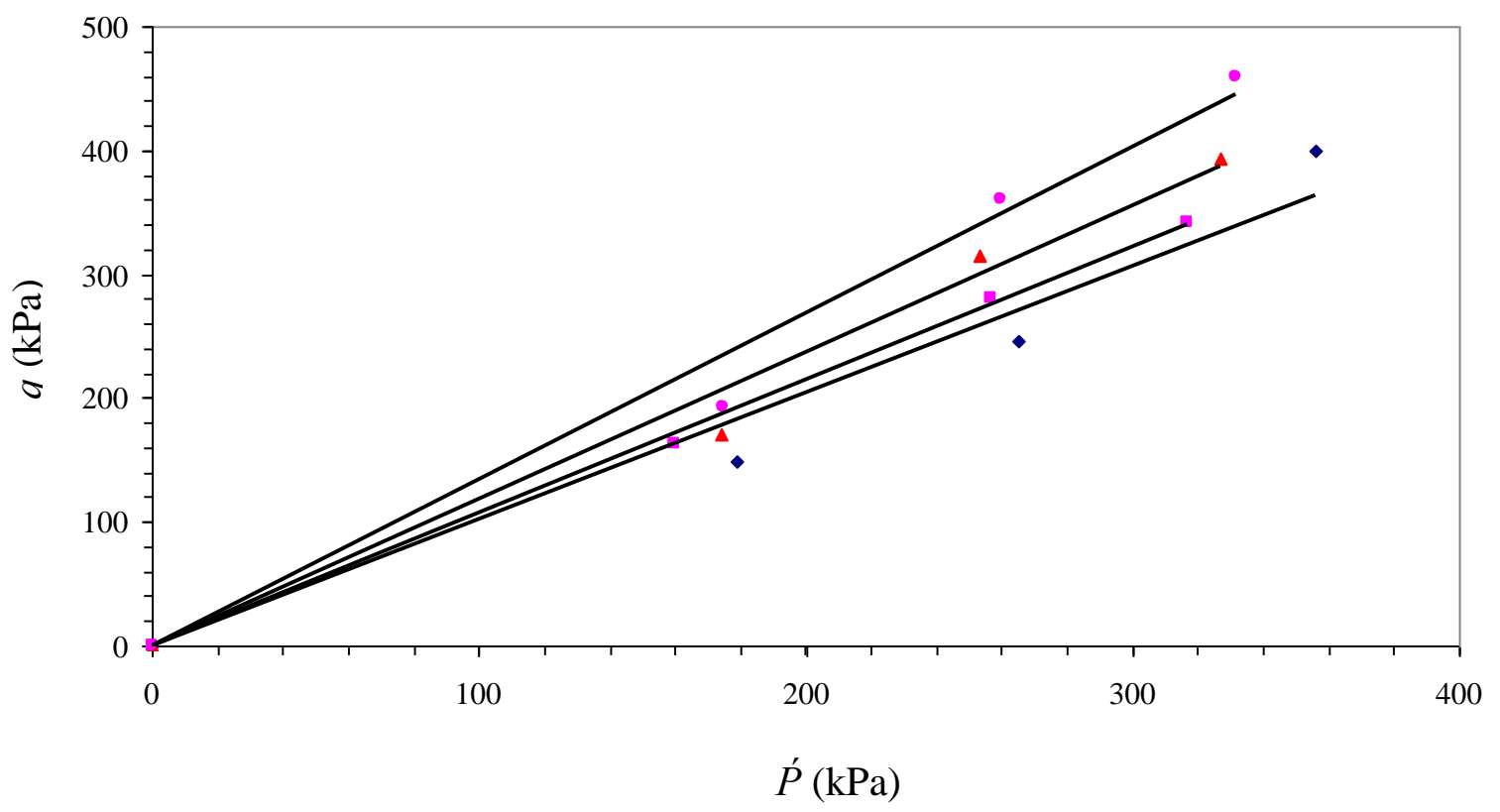

Fig.9. Critical state lines for soll samples with water and ditterent percent of MEG as pore fluid 


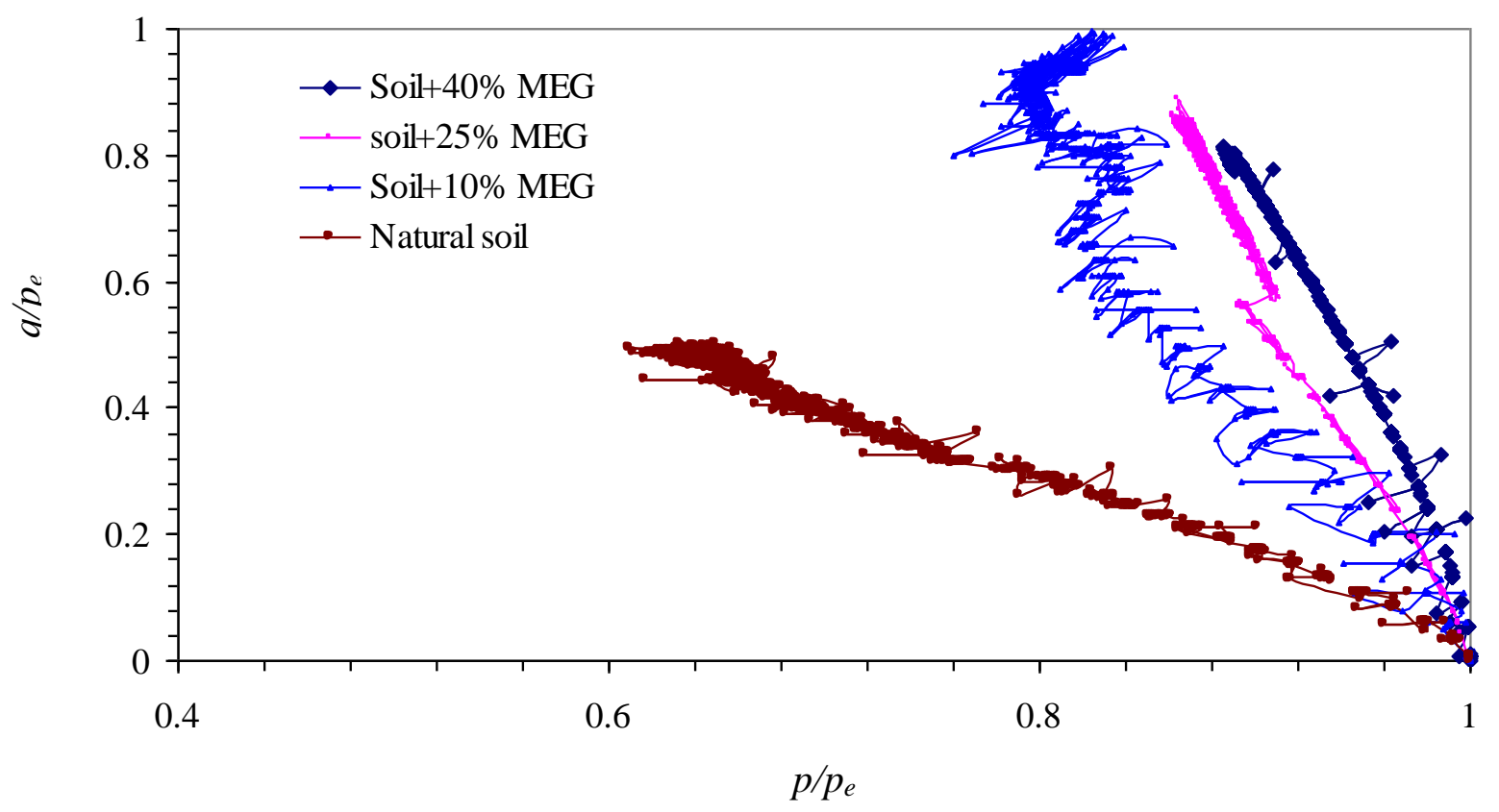

Fig. 10. Roscoe surfaces were plotted in the normalized space of $\frac{q}{p_{e}^{\prime}}: \frac{p}{p_{e}^{\prime}}$ for natural soil and soil contaminated with different percents of MEG 